\title{
THE USE OF KEYWORD AND IMAGERY MNEMONIC FOR VOCABULARIES LEARNING FOR AFL STUDENTS
}

\author{
Risna Rianti Sari \\ Islamic State of University Maulana Malik Ibrahim
}

Email : risnainlearn@gmail.com

$$
\begin{aligned}
& \text { اليوم ، يدرك العديد من الباحثين أن المفردات مهمة وهي جزء من }
\end{aligned}
$$

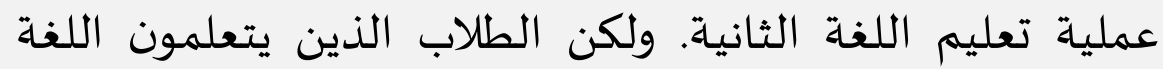

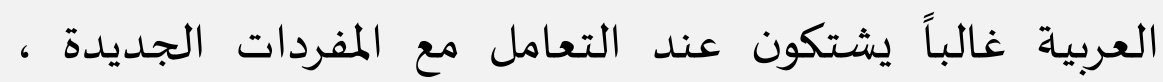

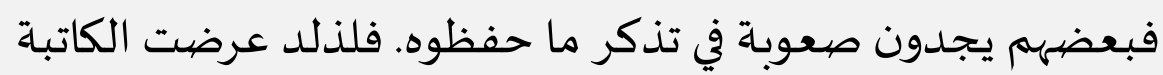

$$
\begin{aligned}
& \text { طريقة تسمى "فن الإستذكار" (mnemonic) لمتعلمي اللغة العربية. }
\end{aligned}
$$

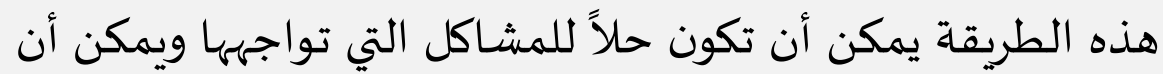

$$
\begin{aligned}
& \text { تحسن من تعليم المفردات العربية. تستكشف هذه المقالة عن } \\
& \text { نظرية mnemonic وكيف إجرائه في حفظ المفردات العربية. هناك لكرديه } \\
& \text { أنواع عديدة من فن الإستذكار نفسها ، ولكن ذكرت الكاتبة نوعان }
\end{aligned}
$$

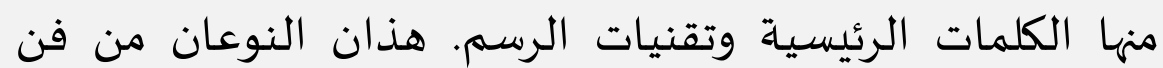

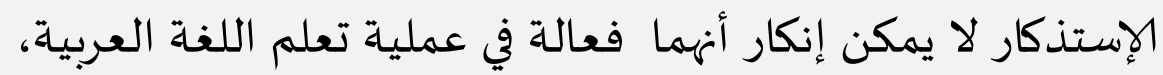

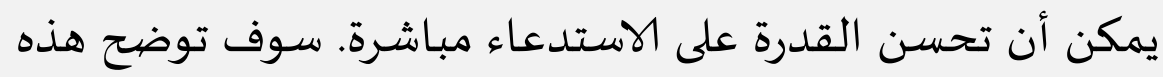

$$
\begin{aligned}
& \text { المقالة حول طريقة ذاكري وكيفية تطبيقه. } \\
& \text { mnemonic ، فن الاستذكار ، مفردات اللغة العربية }
\end{aligned}
$$

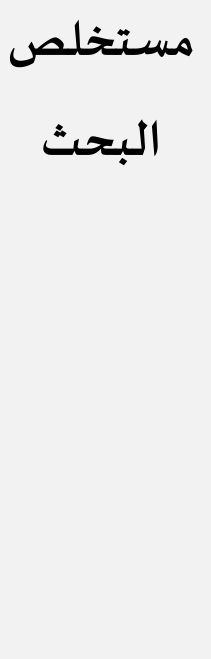

كلمات

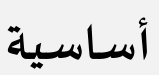

\section{INTRODUCTION}

If we talk about second language learning, it means we also talk about the difficulties. Not only students who learn a certain second language, but employees by second language aslo face the difficulties when they interact with others in the multilingual work place setting (Tranekjær, 2018). These difficulties cause the 
misunderstanding, for example someone who has trouble in pronunciation of the second language makes a different meaning in the ears of the listeners.

The Arabic learners also have their difficulties in learning Arabic language. It is because Arabic has several differences with other languages, for example in sound, structures, and root of the vocabularies (Dajani, Mubaideen, \& Omari, 2014). Also for Arabic learners in Indonesia, they face the difficulties for pronounciating some Arabic letters that are not in Indonesian such as ض ض، ط، ع, غن ق and many more.

Not only that, the Arabic learners also face other difficulties in the learning process. Some of the students have difficulty understanding the Arabic texts, as well as difficulties in expressing Arabic both oral and written because of their lack of vocabularies. At least the beginner students must memorize some Arabic vocabularies to make it easier for them in the learning and evaluation process.

In this paper, the writer will highlight one of the difficulties in Arabic learning; it is about memorizing Arabic vocabularies. So far the vocabulary has a large influence in second language learning as it has unlimited amount. The learner needs many Arabic vocabularies for showing his skills of language, both in speaking or writing.

There are many ways for a learner to memorize Arabic language vocabularies, for example using flash cards, applying the vocabulary into sentences, rote strategy, associating them with images and contexts, watching some Arabic language films or dramas and so on. But the question is how long the vocabularies stick into the learner's brain? Whether the methods of memorizing can make the vocabularies into long term memory for learners?

Rote strategy is still popular in vocabulary learning. A study was conducted on the technique of rote strategy of memorizing English vocabulary for Students College in China. Classes are designed into the control class and the experimental class and the conclusion is that the rote strategy is very effective in acquiring second language vocabulary. But this technique requires persistence and commitment in repeating memorization (Wu, 2014).

Lately the mnemonic method has been widely known and is considered as one of the effective methods of memorizing foreign language vocabulary. They revealed the strengths and weaknesses of this method in various studies. Some of them agree that the mnemonic method can be a solution for memorizing second language vocabularies, but some of them underline that this method cannot completely replace other memorization methods because each individual's brain capacity is different, so the effectiveness depends on the individual learner.

Many researches have positive attitude toward this mnemonic method in second language vocabularies learning. Amiryousefi Mohammad and Saeed Ketabi wrote their research in the Journal of Language Teaching and Research that mnemonic method can improve remembering the vocabularies of foreign language learners, (Amiryousefi \& Ketabi, 2011). Farzaneh revealed that this mnemonic method had been used in real- 
world learning such as intensive English language courses (Anari, Sajjadi, \& Sadighi, t.t.).

Whereas Vanlee Siriganjanavong revealed that the mnemonic method can help beginner EFL students maintain their English vocabularis memories for short and long term memories (Siriganjanavong, 2013). This is because the mnemonic method combines a person's verbal with visual simultaneously so that knowledge of the vocabulary can remain a long time in someone's memory.

The big question appears when the writer conduct this mnemonic method with the difficult in memorizing Arabic vocabularies. Is this method can be used in Arabic language as it can used in English and other languages? So, in her written the writer will shed some light on the way of memorizing Arabic vocabularies by this method. The aim of this study is to present a brief view of mnemonic especially keyword and imagery techniques in Arabic vocabularies learning.

\section{THEORITICAL FRAMEWORK}

Before discussing the meaning of mnemonics, the writer gives a glimpse of the hemisphere of the human brain, because mnemonics are closely related to the use of both the right and left brains. Collaboration is needed for successful memorization using this mnemonic method. Indeed there is no single part of this brain that can work perfectly without being supported by other, it is called the whole brain or the way of global learning (Bobbi Deporter, 2016) .

Both right and left brain has it own functions. The right side of the brain related to creativity, imagination, intuition, music awarness and control the left side of the body. The left brain is responsible for controlling the right side of the body and performs tasks that have to do with logic (mathematics and science), language, number skills, reasoning, and analytic thought.

Even it has different functions but actually the right brain and the left brain can work together to make someone's abilities are more maximal. For example someone who has a tendency of the left brain can incorporate music into his learning experience so as to provide positive feedback and make the brain more effective. To balance these two hemispheres, exercises are needed, one of the exercise is the mnemonic method, which collaborates between the two hemispheres of the brain. That is between memorizing which is the task of the left brain and visualizing which is the task of the right brain.

\section{Mnemonic definition}

Basically mnemonic is a method used to stimulate a person's memory. The word mnemonic is actually not new because this word has existed since the Greek era where the mnemonic word was taken from the name of an ancient Greek god, Mnemosyne, which means the god of memory (Amiryousefi \& Ketabi, 2011). Mnemonics at that 
time were only limited to memorizing speeches by a leader so that listeners were impressed by their ability to remember speeches and debate in government, but as time went on mnenonic was used as a general memory booster method.

Experts provide a similar definition of mnemonics that mnemonics are techniques or a verbal and visual device that can increase a person's memory capacity and remember new information easily (Solso 1995 in Siriganjanavong, 2013). RiederBünemann (2012) calls mnemonics as mnemotechnics for thinking that mnemonics are a technique or tool that can aid a person's memory (Ożańska-Ponikwia, t.t.).

The brief definition is presented by Higbee (1979) that mnemonics are helpers of memory. Bellezza (1981) adds that mnemonics is a technique of transferring material into a format that is easy to learn and remember (Cohen, 1987). Conclusions from the understanding of mnemonics is a technique of utilizing the human brain to maximize memory so it can help a person to remember the information and make that information stored in long-term memory.

Mnemonics relate to one's imagination and how they associate it, because this association will provoke memories even for a long time. In the other words, mnemonic forces someone to coordinate the right brain and left brain maximally. There are many different methods for coordination, for example by making stories, connecting words, visualizing words, making ideas and fantasies.

\section{Mnemonic classification}

There are various kinds of mnemonic classifications according to experts, Thompson (1987) classified mnemonics into five parts i.e. language, spatial, visual, physical response and verbal methods, while Baddeley (1999) only categorizes into two, both are visual imagery strategies and verbal strategies (Amiryousefi \& Ketabi, 2011). Classification of the mnemonic form according to Jensen (2002) are loci, word marker, related word, cutting, acronym and acrostic (Laili \& Fauziyah, t.t.).

Based on its function, the mnemonic form can be grouped into several functions , for example to memorize places can be used loci method, spatial or peg word techniques. To memorize numbers can be used cutting techniques and a number system, to memorize related sequential words can be used acronyms and acrostics. As for memorizing absurd words, foreign languages, and terms can be used story techniques, keywords, imagery and related words.

However, the types of mnemonics are not absolutely used for only one purpose. Suppose the loci technique can also be used to memorize foreign language vocabularie with the terms that the vocabularies are related. To memorize numbers, you don't have to use cutting techniques, but you can also use visual images techniques. As with keyword techniques that are identical to the technique of memorizing foreign language vocabulary, it can also be used to memorize a speech text. 


\section{METHOD}

This is a library research paper which will involves identifying and locating relevant information, and expressing the writer's idea. The writer use the descriptive method, the secondary sources in this paper are books and journal aricles.

\section{DISCUSSION}

The object of mnemonic in this paper is Arabic vocabulary. Vocabulary or in Arabic al-mufradat means a collection of words that used in a particular language (Fajriah, 2015). The purpose of this mnemonic is to help students master or memorize Arabic vovabularies which can be used and utilized in communicating and interacting with other people who use similar languages.

Association is the common process in mnemonic techniques in second language learning, association in the form of stories, sounds or images related to the second language. The writer will present two forms of mnemonics that can help students, especially in learning Arabic in memorizing vocabularies both are keyword method and imagery. The explanation and example of both wI'll be presented in the next paragraph.

\section{Keywords}

The use of keywords in foreign language vocabulary learning has been supported by several studies which were largely inspired by Atkinson $(1972,1975)$ which discussed a lot of keyword methods in mnemonics where foreign language vocabulary can be remembered by relating it to a keyword, matching sounds with first language, and images which involving both languages even first and second languages (Ożańska-Ponikwia, t.t.).

According to the Mastropieri there are three stages in developing keywords as a method for memorizing, the first is reconstructin, search for keywords, something familiar to the learner's ears, sounds that are similar to new vocabulary to be learned. the second is relating, connect the keywords to the meaning of the new vocabulary. and the last is retrieve, teach the learner how the stages for remembering the vocabulary effectively (Bakken, 2011).

Example for stages above can be seen when teaching the word ruzzun means padi (rice). First step is finding the keyword that sounds familiar to the student- arus (flowing water). associate the keyword to the meaning that ada padi di arus air (there are rice in flowing water). The Teaching process : "When I say what does ruzzun?, first think of the keyword arus), then what are there in the flowing water (arus)?, there are rice in flowing water, then the answer is rice. The teacher also teach the student how to remember and recall that vocabularies.

The majority of empirical studies about mnemonics and their application to second language learning show that keywords is a powerful method of memorizing 
compare to other mnemonics. Here is the results of keywords studies which show that beginner students who are less skilled can save a lot of foreign language vocabularies for short and long term memory (Siriganjanavong, 2013) .

Keywords are not only useful for second language learners at a young age, but older people can use these keywords to learn a second language. This was proven by Gruneberg \& Pascoe '(1996) in his study of adult women with an average age of 45 years that keywords produced a very significant development in language acquisition, they were more productive in learning Spanish than those who did not get keyword treatment (Siriganjanavong, 2013).

The word used as a keyword is the first language word that has the similar sound from the second language. For example, malaabis, which means clothes, can be used malas which is from Indonesian as the keyword, with association in the brain that "melihat pakaian-pakaian yang menumpuk untuk disetrika menjadikan kita malas" (seeing clothes piled up to be ironed makes us lazy). Other example is safar, which means travel, can be used tepar (tired) as a keyword with association "setelah melakukan perjalanan jauh kita menjadi tepar"(after making a long journey, we become very tired).

The choice of keywords between one person and another can be different, depending on the language experience he has and how he connects the right and left brain to form an association. Unique keywords will make the word easier to remember. For example, the use of regional language as the mother language of someone which is close to everyday life, the current slang language and can even use sounds that are similar to the foreign word.

The above are only an example of how to use keywords to memorize. learners can be more creative by using keywords in their everyday slang language. Besides the slang language they can also take advantage of their regional languages in this condition the learner can use Javanese language rather the vocabulary associations with keywords are more maximal.

\section{Imagery}

The imagery technique in second language learning also refers to keywords in the form of visual images. The foreign vocabulary is recoded into similar image or picture. When the learner find that foreign vocabulay the learner can immediately find the meaning because there are connection between word and picture which has been formed and it will reappear in the learner's brain (Cohen, 1987).

For example the Arabic word taswir which means photographing, the learner can visualize a camera in a bag (tas) so he will remember the word taswir. The imagery of the camera signifies that the word is related to photograph while tas (bag) because the first syllable of the Arabic language from taswir (photographing) is tas. Another example is the tajir in Arabic which means trader, the learner can visualize a rich or wealthy trader because tajir in Indonesian means rich. 


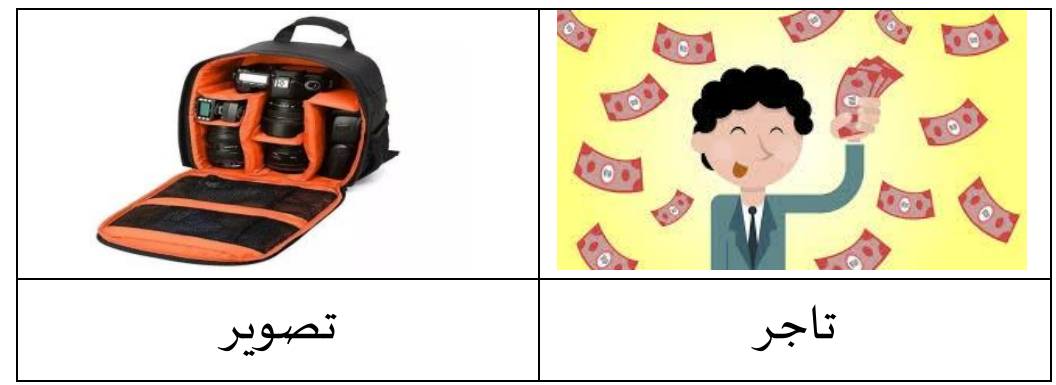

Age is considered in the use of imagery techniques in memorizing foreign language vocabulary. At the elementary level learners have not been able to adopt this technique, the teachers should provide an overview, so it is more effective than let them give their own image to a foreign word. As with adult learners, giving their own imagery is better because they can think more thoroughly (Cohen, 1987).

Mnemonic for many educationists is not important, because memorization were the lowest skills in Bloom's taxonomy (the hierarchy of the learning process. It was said that applying, understanding, evaluating, analyzing and the higher creating are more important. The disadvantages of this method also felled by the person of weak ability to create or imagine, it may not be easy to make up a story. The amounts of vocabulary is limited by using this method.

\section{CONCLUSIONS}

Mnemonics have been developed in the field of second language learning, so it can also be applied to memorize Arabic vocabulary by Arabic learners. Many studies assess that mnemonics are effective in remembering and maintaining memory in the long term. The mnemonic method especially keyword and imagery are methods that used to help students remember Arabic vocabulary and they can memorize in their long term memorize.

Mnemonics can train students to think creatively in everything. Not only in Arabic lessons, if you are accustomed to associating the right brain and left brain, it will be useful in everyday life, for example memorizing numbers, new friends' names or other things. In addition, learning to use the mnemonic method can make the learning process more enjoyable and reduce the dense pressure of the students' schedules.

But this techniques will not be able to replace other methods of memorizing and remembering foreign language vocabulary, because each individual has his own thoughts and brain intelligence that are different. This method is very dependent on the creativity of the brain of each individual, and only helps, if students of foreign languages feel that it is not suitable for this method, then they can find their own methods and techniques that are right for them. 


\section{BIBILIOGRAPHY}

Amiryousefi, M., \& Ketabi, S. (2011). Mnemonic Instruction: A Way to Boost Vocabulary Learning and Recall. Journal of Language Teaching and Research, 2(1). https://doi.org/10.4304/jltr.2.1.178-182

Anari, F. K., Sajjadi, M., \& Sadighi, F. (t.t.). The magic of mnemonics for vocabulary learning of a second language. International Journal of Language and Linguistics, 6.

Bakken, J. (2011). Mnemonic Strategies: Success for the Young-Adult Learner, 7(2), 7.

Bobbi Deporter, M. H. (2016). Quantum Learning : Membiasakan Belajar Nyaman dan Menyenangkan (II). Bandung: Kaifa.

Cohen, A. D. (1987). The Use of Verbal and Imagery Mnemonics in Second-Language Vocabulary Learning. Studies in Second Language Acquisition, 9(01), 43. https://doi.org/10.1017/S0272263100006501

Dajani, B. A. S., Mubaideen, S., \& Omari, F. M. A. (2014). Difficulties of Learning Arabic for Non-native Speakers. Procedia - Social and Behavioral Sciences, 114, 919-926. https://doi.org/10.1016/j.sbspro.2013.12.808

Fajriah, Z. (2015). PENINGKATAN PENGUASAAN KOSAKATA BAHASA ARAB (MUFRADAT) MELALUI PENGGUNAAN MEDIA KARTU KATA BERGAMBAR, 9, 20.

Laili, N., \& Fauziyah, N. (t.t.). PENGEMBANGAN BUKU SAKU DENGAN METODE MNEMONIK DALAM PEMBELAJARAN HURUF KANJI TINGKAT DASAR DI SMA DARUL ULUM 2 UNGGULAN BPPT CIC (CAMBRIDGE INTERNATIONAL CENTRE) JOMBANG, 10.

Ożańska-Ponikwia, K. (t.t.). THE ROLE OF MNEMONICS IN THE PROCESS OF L1 AND L2 LANGUAGE LEARNING. Language Learning, 8.

Siriganjanavong, V. (2013). The Mnemonic Keyword Method: Effects on the Vocabulary Acquisition and Retention. English Language Teaching, 6(10). https://doi.org/10.5539/elt.v6n10p1

Tranekjær, L. (2018). The interactional management of 'language difficulties' at work L2 strategies for responding to explicit inquiries about understanding. Journal of Pragmatics, 126, 78-89. https://doi.org/10.1016/j.pragma.2017.10.003

Wu, Q. (2014). A Rote Strategy in Memorizing Vocabulary for ESL Learners. Procedia - Social and Behavioral Sciences, 143, 294-301. https://doi.org/10.1016/j.sbspro.2014.07.408 